\title{
1. Social rights in international law: categorization versus indivisibility
}

\author{
Manfred Nowak
}

\section{INTRODUCTION}

This introductory contribution starts by defining social rights as a subcategory of the broader category of economic, social and cultural rights in accordance with the ordinary meaning of these terms in international human rights law. It continues with a short history of how economic, social and cultural rights developed as an antithesis to the bourgeois concept of civil and political rights during the nineteenth and early twentieth centuries. Although the Universal Declaration of Human Rights (UDHR) of 1948 achieved a remarkable synthesis between both broad dimensions of human rights, the Cold War was characterized by a fierce political battle between the Western and the socialist concepts of human rights, which led to the adoption of two International Covenants, based on the doubtful ideological assumption that there was a fundamental legal difference between civil and political rights on the one hand, and economic, social and cultural rights on the other, with respect to the nature of state obligations and adequate measures of national and international monitoring and implementation. After the end of the Cold War, this legal categorization was gradually replaced by the doctrine of the equality, interdependence and indivisibility of all human rights and the recognition of obligations of states to respect, protect and fulfil, which apply equally to all human rights. These different types of state obligations are explained by means of various examples, above all in the field of social rights laid down in Article 25 UDHR as well as in Articles 9 to 12 of the International Covenant on Economic, Social and Cultural Rights (ICESCR) of 1966.

\section{QUESTIONS OF DEFINITION}

The term 'social rights' is not clearly defined in international law. In the Preamble to the European Social Charter (ESC) 1961, for example, the term 'social rights' is used to distinguish the rights enumerated in the ESC from the 'civil and political rights and freedoms' specified in the European Convention on Human Rights (ECHR) and its first Additional Protocol. Since the ESC contains a full range of rights, including the right to work, the rights to vocational guidance and training, the right to protection of health, the right to social security and the right of migrant workers and their families to protection and assistance, we can draw the conclusion that the Council of Europe $(\mathrm{CoE})$ applies a fairly broad definition of social rights. The Revised ESC of 1996 maintained this broad definition, although the Preamble also refers to 'economic, social and cultural rights'.

The United Nations, the Organization of American States (OAS) and other regional organizations, including the African Union, on the other hand, primarily use the composite term 'economic, social and cultural rights' for the broad category of rights which in Europe seem 
to be called 'social rights'. The most important documents in this respect are the ICESCR of 1966 and the Additional Protocol to the American Convention on Human Rights in the Area of Economic, Social and Cultural Rights ('Protocol of San Salvador') of 1988, which both cover a wide range of human rights. ${ }^{1}$

However, neither of these treaties clearly define, for example by means of different chapters, which of the rights covered therein are social rights, as distinguished from economic rights on the one hand and from cultural rights on the other. Nevertheless, there is a certain logical structure in the ICESCR. The first three rights in Articles 6 to 8 (right to work, rights in work, right to form and join trade unions, right to strike) are clearly economic rights as they refer to economic activities, and are followed by social rights in Articles 9 to 12 (right to social security, protection of the family with special emphasis on the rights of mothers and children, right to an adequate standard of living, including the rights to food, housing and clothing, right to health), and by cultural rights in Articles 13 to 15 (right to education, right to take part in cultural life, right to enjoy the benefits of scientific progress, right to intellectual property for scientific, literary or artistic production).

The structure of the ICESCR has its roots in the UDHR of 1948, which encompasses civil, political, economic, social and cultural rights in a very clear order. The UDHR starts in Article 1 with the famous words that '[a]ll human beings are born free and equal in dignity and rights', which reflect the concept of human dignity, as defined by Immanuel Kant, ${ }^{2}$ as the major source of legitimacy for all human rights. The second umbrella clause in Article 2 defines the principle of equality in terms of a broad non-discrimination clause. Articles 3 to 21 enumerate the classical civil and political rights up to the most important political right in Article 21 to take part in the government of one's country, directly or through freely chosen representatives, including the right of equal access to public service and the right to vote and be elected in periodic, genuine, secret and free elections based upon universal and equal suffrage. The 'freedom rights' in Articles 18 to 20, namely freedom of thought, conscience and religion, of opinion, expression and information and of assembly and association, were inserted between civil and political rights as they serve both a liberal and a political purpose for well-functioning democratic governance. ${ }^{3}$ That the right to own property is not an economic right, as often wrongly assumed, but a civil right is clear from its position in Article 17. Article 22 is another umbrella provision, which introduces the concept of 'economic, social and cultural rights' and makes a second reference to human dignity by stressing that these rights are indispensable for the dignity and free development of human personality. Thereafter, economic, social and cultural rights are spelled out in more detail. Article 23 covers most economic rights, such as the right to work, the right to free choice of employment, the right to just and favourable conditions of work, the right to protection against unemployment and the right to form and join trade unions. The right to rest and leisure in Article 24 is also an economic right, as it is based on a reasonable limitation of working hours and provides for periodic holidays with pay. All

See already the Preamble and Chapter III of the American Convention on Human Rights of 1969 , which refer to 'economic, social and cultural rights' as distinct from 'civil and political rights'. Similar language can be found in the Preamble to the African Charter on Human and Peoples' Rights of 1981 and in other regional human rights treaties.

2 On the relationship between human dignity and human rights see Manfred Nowak, Menschenwürde und Menschenrechte (2018) 32ff, with reference to Kant's definition.

3 On the meaning of political rights see Manfred Nowak, Politische Grundrechte (1988). 


\section{Research handbook on international law and social rights}

social rights are covered by Article 25, which provides for the right to an adequate standard of living, including the rights to food, clothing, housing, medical care and social security, as well as special care and assistance for motherhood and childhood. Articles 26 and 27 then specify the two main cultural rights to education and participation in cultural life.

In legal literature, the division between economic, social and cultural rights does not always follow this structure. Asbjørn Eide, for example, regards the right to social security and certain rights which are not covered by the ICESCR, such as the right to property, as 'economic rights', and the rights of minorities in Article 27 of the International Covenant on Civil and Political Rights (ICCPR) as 'cultural rights'. ${ }^{4}$ I disagree with this categorization, as it disregards the terminology and structure of the UDHR and the two Covenants. However, Eide rightly considers the right to an adequate standard of living as the 'core' of social rights. ${ }^{5}$ I also recognize that the distinction between these three categories is not always waterproof and that the economic right to form and join trade unions is also covered by Article 22 ICCPR. Nevertheless, I use the terms 'economic rights', 'social rights' and 'cultural rights' by following the logical structure of the UDHR and ICESCR as outlined above. This means that I use the term 'social rights' in the narrow sense of the rights covered by Article 25 UDHR as well as Articles 9 to 12 ICESCR, whereas I prefer to use the term 'economic, social and cultural rights' when I refer to this entire category of rights as distinct from the category of 'civil and political rights', as enumerated in the ICCPR. ${ }^{6}$ I wish to stress, however, that these terms are purely used for definitional purposes and do not entail any legal consequences, as I will show below.

Based upon the 'three generations theory' developed by Karel Vašák already during the late 1970s, ${ }^{7}$ many scholars use the term 'first generation' for civil and political rights, 'second generation' for economic, social and cultural rights and 'third generation' for collective rights of peoples or 'solidarity rights'. Although this theory has a certain value in explaining the historical development of these three categories or dimensions of human rights, I nevertheless prefer to avoid these terms, in order to prevent certain misunderstandings or misconceptions which are often associated with the 'three generations theory'. 8

\section{SHORT HISTORY OF ECONOMIC, SOCIAL AND CULTURAL RIGHTS}

Long before human rights were codified in international law, they were gradually developed in domestic constitutional law, starting from the French and American Revolutions of the late

\footnotetext{
4 Asbjørn Eide, 'Economic, Social and Cultural Rights as Human Rights' in Asbjørn Eide, Catarina Krause and Allan Rosas (eds), Economic, Social and Cultural Rights (2001) 9, 17ff.

5 Ibid., 17.

6 For the meaning of 'civil rights' and 'political rights' see Manfred Nowak, UN Covenant on Civil and Political Rights - CCPR Commentary (2005) 564ff.

7 See Karel Vašák, 'A 30-Year Struggle: The Sustained Efforts to Give Force of Law to the Universal Declaration of Human Rights' (1977) XXX UNESCO Courier 29.

8 Cf. also Asbjørn Eide and Allan Rosas, 'Economic, Social and Cultural Rights: A Universal Challenge' in Asbjørn Eide, Catarina Krause and Allan Rosas (eds), Economic, Social and Cultural Rights (2001) 3, 4 .
} 
eighteenth century. ${ }^{9}$ Based on the rationalistic doctrine of natural law and on theories of the social contract developed by philosophers such as John Locke, Thomas Paine, Jean-Jacques Rousseau and Samuel Pufendorf, the bourgeois concept of civil and political rights was gradually developed in the American Declaration of Independence of 1776; the Bills of Rights of the newly independent American states, most notably the Virginia Bill of Rights of 1776; and the famous French Declaration of the Rights of Man and the Citizen 1789. Liberalism and democracy are the two main philosophical ideas behind the concept of civil (liberal) rights of men, ${ }^{10}$ as distinguished from the political (democratic) rights of citizens in the French Declaration. Liberal freedom was defined in Article 4 of the French Declaration as the right of all men to do whatever is not injurious to others, and political freedom in Articles 2 and 6 as the right of citizens to participate in the democratic decision making of the people. ${ }^{11}$

In his essay 'On the Jewish Question', Karl Marx developed in 1843 a fundamental critique of the very concept of civil and political rights, as contained in the French Declaration as rights of men and citizens:

Above all, we note that the so-called rights of man, the droits de l'homme as distinct from the droits du citoyen, are nothing but the rights of a member of civil society, i.e. the rights of egoistic man, of man separated from other men and from the community. ${ }^{12}$

In the right to property, Marx recognized the prototype of a civil right, that is, a right of egoistic self-interest, and the source of the economic exploitation of human beings. The socialist concept of human rights gradually developed as an antithesis to the bourgeois concept of civil rights, above all the right to private property. Instead of civil rights, socialist thinkers, including Friedrich Engels, Pierre-Joseph Proudhon and Louis Blanc, advocated the right to equality in the social and economic sphere as well as the early recognition of certain economic, social and cultural rights, such as the right to education, the right to work and the rights of orphans and the elderly to be supported by the state. After the First World War, economic, social and cultural rights were included, for example, in the 1919 Weimar Constitution and certain Latin American constitutions (such as the 1917 Mexican constitution), and promoted by the International Labour Organization (ILO), established on the basis of the Peace Treaty of Versailles in 1919. The best known catalogue of economic, social and cultural rights was contained in the Stalin Constitution of the Soviet Union of 1936, which included the rights to work, rest and leisure, social insurance, free medical services and education, as well as equal rights of women in all spheres of economic, cultural, social and political life.

9 On the history of human rights see, e.g., Felix Ermacora, Menschenrechte in der sich wandelnden Welt (Vol I, 1974); Micheline R Ishay, The History of Human Rights - From Ancient Times to the Globalization Era (2004); Jack Mahoney, The Challenge of Human Rights - Origin, Development and Significance (2007); Lynn Hunt, Inventing Human Rights (2008); Manfred Nowak, Menschenrechte Eine Antwort auf die wachsende ökonomische Ungleichheit (2015) 49ff; Manfred Nowak, Human Rights or Global Capitalism - The Limits of Privatization (2017) $7 \mathrm{ff}$.

10 The expression 'man' (homme) was meant to only refer to men, while women were excluded from the idea of 'human rights' both in theory, law and practice. When in 1790 Olympe de Gouge drafted a first Declaration of the Rights of Woman in reaction to the French Declaration of 1789, she was convicted and executed for her counterrevolutionary activities under the terror regime of Robespierre in 1793. For the text of this Declaration see Micheline R Ishay, The Human Rights Reader (1997) 140.

11 See Nowak, Human Rights or Global Capitalism (n 9), 10.

12 Karl Marx, On the Jewish Question (1843), quoted from Ishay (n 10), 195. 


\section{Research handbook on international law and social rights}

The United Nations was created in 1945 in reaction to two World Wars, the Great Depression, the rise of fascism and the horrors of the Holocaust. ${ }^{13}$ The three major aims and objectives stipulated in the UN Charter are, therefore, international peace and security, development and human rights. The 'four freedoms speech', delivered by US President Franklin Delano Roosevelt to Congress on 6 January 1941 and referring to the freedom of speech and expression, the freedom to worship God in his own way, freedom from want and freedom from fear, ${ }^{14}$ had a major influence on the Charter of the new world organization. Sixty years later, UN Secretary General Kofi Annan built his well-known report, 'In larger freedom' - which aimed at a fundamental reform of the United Nations - on Roosevelt's concepts of 'freedom from fear' and 'freedom from want'. Human security means a world in which everybody can live in freedom from fear and violence, while human development aims at a world order in which everybody can live in freedom from want and poverty. Annan stressed the interdependence of the three major goals of the United Nations as follows: 'Accordingly, we will not enjoy development without security, we will not enjoy security without development, and we will not enjoy either without respect for human rights. ${ }^{15}$ Human rights are, therefore, the cornerstone on which the two other pillars, security and development, need to be built. At the same time, the terms 'freedom from fear' and 'freedom from want' also relate to the two antagonistic concepts of human rights as they had developed since the late eighteenth century, namely the bourgeois (Western) concept of civil and political rights, and the socialist concept of economic, social and cultural rights. The Charter of the United Nations reflects the three aims and objectives as follows:

We the peoples of the United Nations determined to save succeeding generations from the scourge of war, which twice in our lifetime has brought untold sorrow to mankind, and to reaffirm faith in fundamental human rights, in the dignity and worth of the human person, in the equal rights of men and women and of nations large and small, and to establish conditions under which justice and respect for the obligations arising from treaties and other sources of international law can be maintained, and to promote social progress and better standards of life in larger freedom.

Although the text of the UN Charter contains seven references to human rights, this term has nowhere been defined. This important and difficult task was entrusted to the Commission on Human Rights, which was established in 1946 as a functional commission of the Economic and Social Council (ECOSOC) in accordance with Article 68 of the Charter. The Commission consisted of 18 states from all world regions, represented by well-known personalities, such as Eleanor Roosevelt (USA) in the chair, ${ }^{16}$ Peng Chung Chang (China), Hansa Mehta (India),

13 The following is based on the detailed historical analysis in Nowak, Human Rights or Global Capitalism (n 9), 17ff.

14 See Ishay (n 10), 403.

15 Kofi Annan, 'In Larger Freedom: Towards Development, Security and Human Rights for All' (21 March 2005) UN Doc A/59/2005, para 17. This document can be considered as the main legacy to a world in turmoil of Kofi Annan, who passed away in August 2018. Unfortunately, most of his reform proposals were not taken up by world leaders during their summit in September 2005.

16 See Mary Ann Glendon, A World Made New - Eleanor Roosevelt and the Universal Declaration of Human Rights (2001). 
Charles Malik (Lebanon), ${ }^{17}$ Alexandre Bogomolov (USSR), René Cassin (France) ${ }^{18}$ and Hernan Santa Cruz (Chile). The history of the drafting of the UDHR in the Commission is well known and shall not be repeated here. ${ }^{19}$ What is important for our purpose is the fact that the drafters managed within the short period of two years, in which the antifascist consensus was still stronger than the divisions of the ensuing Cold War, to develop a synthesis between different and antagonistic concepts of human rights. The UDHR, which was formally adopted on 10 December 1948 by the UN General Assembly in Paris, contains all major civil and political rights, including the controversial right to own property (Article 17) in Articles 1 to 21, all major economic, social and cultural rights in Articles 22 to 27, the vision of a social and international order in which the rights and freedoms of the Declaration can be fully realized in Article 28, duties to the community in Article 29 and a clause prohibiting abuse in Article 30.

This synthesis shows that the often repeated argument that human rights are simply a Western concept and invention is wrong. However, it is also a widespread misconception that the Soviet Union and its allies fought strongly against the Western states to achieve this synthesis by having economic, social and cultural rights included in this most important human rights document in human history. ${ }^{20}$ Although it is true that the British and Australian representatives repeatedly tried to avoid the inclusion of economic, social and cultural rights, the discussions in the Commission and the Third Committee of the General Assembly, which was chaired by Charles Malik, show a much more diverse picture. According to Johannes Morsink, it is primarily 'the Latin American socialists - and John Humphrey as their conduit - to whom we owe the presence of these rights in the Declaration'. ${ }^{21}$ John Humphrey, a young Canadian professor who had been appointed in 1946 as the first director of the UN Division of Human Rights, was entrusted by Eleanor Roosevelt with the task of preparing a first draft of the Declaration in early 1947. In his memoirs, he even claimed a certain ownership for the inclusion of economic, social and cultural rights. ${ }^{22}$ Others argue, however, that Humphrey clearly overrated his contribution in this regard. ${ }^{23}$ In fact, the French Nobel prize laureate René

17 See Habib C Malik (ed.), The Challenge of Human Rights - Charles Malik and the Universal Declaration (2000).

18 See Marc Agi, René Cassin 1887-1976 (1998).

19 See, e.g., John P Humphrey, Human Rights and the United Nations: A Great Adventure (1984); Johannes Morsink, The Universal Declaration of Human Rights - Origin, Drafting, and Intent (1999); Guðmundur Alfreðsson and Asbjørn Eide (eds), The Universal Declaration of Human Rights - A Common Standard of Achievement (1999); William Schabas (ed.), The Universal Declaration of Human Rights - The Travaux Préparatoires (2013); Vinodh Jaichand and Markku Suksi (eds), 60 Years of the Universal Declaration of Human Rights in Europe (2009); Johannes Morsink, Inherent Human Rights: Philosophical Roots of the Universal Declaration (2009); Barend Van Der Heijden and Bahia Tahzib-Lie, Reflections on the Universal Declaration of Human Rights: A Fiftieth Anniversary Anthology (1998); M Glen Johnson and Janusz Symonides, The Universal Declaration of Human Rights: A History of its Creation and Implementation 1948-1998 (1998).

20 See, e.g., Ashild Samnoy, 'The Origins of the Universal Declaration of Human Rights' in Guðmundur Alfreðsson and Asbjørn Eide (eds), The Universal Declaration of Human Rights A Common Standard of Achievement (1999) 3, 11; Asbjørn Eide and Wenche Barth Eide, 'Article 25' in ibid., 523, 528 .

21 Morsink 1999 (n 19), xiv (and 157ff).

22 Humphrey (n 19), 32: 'It is by no means certain that economic and social rights would have been included in the final text if I had not included them in mine.'

${ }^{23}$ See, e.g., Bard-Anders Andreassen, 'Article 22' in Asbjørn Eide et al (eds), The Universal Declaration of Human Rights: A Commentary (1992) 319, 331. 


\section{Research handbook on international law and social rights}

Cassin, who was requested in June 1947 to prepare a second draft on the basis of Humphrey's outline, and the Chilean human rights expert Hernán Santa Cruz seemed to have played an at least equally decisive role in pushing for the inclusion of economic, social and cultural rights. However, Cassin, who was later portrayed by the French government as the true 'father' of the UDHR, was also accused of having overstated his own role. ${ }^{24}$ One should also not forget the important role of Eleanor Roosevelt, who as Chair often had to find a compromise. After all, since her husband had introduced the New Deal legislation and the 1935 Social Security Act in the United States and had advocated for the equal recognition of the 'freedom from want' in his 'four freedoms speech', it would have been difficult for her to speak against the inclusion of economic, social and cultural rights. ${ }^{25}$

We can, therefore, conclude that there were many reasons for the inclusion of economic, social and cultural rights in the UDHR. On the one hand, the Soviet Union and its allies would have strongly objected if the UDHR had only contained Western civil and political rights. However, these rights were not seen (yet) as an exclusive domain of socialist states. They had been included already, as stated, in the Weimar Constitution of 1919 and in various Latin American constitutions. They were defended by the ILO, by social democrats all around the world and also by Christian philosophers. Under the imprint of the Great Depression, which had contributed to the rise of communist and fascist movements and regimes, social security legislation was introduced in the United States and many other states, inspired by the economic theories of John Maynard Keynes. ${ }^{26}$ In other words, at a time when the antifascist consensus in the international community and the desire to build a peaceful and more just social world order out of the ashes of the Second World War was still stronger than the dividing forces of the Cold War, there was also a fairly broad agreement on the need to find a fair balance between civil and political rights and freedoms, on the one hand, and economic, social and cultural rights, on the other.

When Charles Malik, a Christian professor of philosophy from Lebanon acting as Chair of the Third Committee of the General Assembly, delivered a powerful speech on the eve of the adoption of the UDHR requesting that the delegates of the General Assembly in Paris vote for the Declaration, he proudly observed:

Every member of the United Nations has solemnly pledged itself to achieve respect for and observance of human rights. But, precisely what these rights are, we were never told before, either in the Charter or in any other international instrument. This is the first time the principles of human rights and fundamental freedoms are spelled out authoritatively and in precise detail. I know now what my government pledged itself to promote, achieve and observe when I had the honour to sign the Charter of San Francisco, on its behalf, on 26 June $1945 .^{27}$

One day later, the UDHR was adopted with a vote of 48 states in favour, none against and eight abstentions. ${ }^{28}$

\footnotetext{
24 See, e.g., Morsink 1999 (n 19), 8.

25 See, e.g., Glendon (n 16), 42f, $115 \mathrm{ff}, 155 \mathrm{ff}$.

${ }_{26}$ See John Maynard Keynes, The General Theory of Employment, Interest and Money (1936, reprinted 1977).

27 Charles Malik, 'Speech of Thursday 9 December 1948' in Habib C Malik (ed.), The Challenge of Human Rights - Charles Malik and the Universal Declaration (2000) 117, 124f.

28 UNGA Res 217A (10 December 1948). The eight abstaining states were Byelorussia, Czechoslovakia, Poland, Saudi Arabia, South Africa, Ukraine, the USSR and Yugoslavia. The socialist
} 
In accordance with its original three-step approach of drafting first a non-binding declaration, and thereafter a binding convention and measures of implementation, the Commission started in 1949 to work on a convention. In 1950 the General Assembly, emphasizing the interdependence of all categories of human rights, explicitly called upon the Commission to adopt a single convention..$^{29}$ However, the memories of the horrors of the Second World War started to fade as the Cold War was intensifying, not least due to the Korean crisis. In order to pursue their goal of submitting civil and political rights to a monitoring system of individual complaints before an independent court, as achieved by the CoE with the adoption of the ECHR in 1950, and at the same time side-lining economic, social and cultural rights, the United States suggested in 1951 to split the International Bill of Rights into two Covenants. John Humphrey observed in his memoirs that the American suggestion had provoked a 'large ideological controversy and decision', which had 'split the United Nations down the middle'. ${ }^{30}$ A group of likeminded states from different world regions, including Chile, Egypt, Pakistan and Yugoslavia, had moved to reaffirm the decision of 1950, but the Americans strongly lobbied for splitting the Covenant and managed to reverse the 1950 decision by a very narrow vote. ${ }^{31}$ This was a decisive turn in the history of the International Bill of Rights. From that point onward the Commission (until 1954) and later the Third Committee of the General Assembly drafted a 'Western' and a 'Socialist' Covenant with two different types of state obligations and two different sets of international monitoring procedures in mind. ${ }^{32}$ After highly controversial discussions on the monitoring mechanisms in the Third Committee, the General Assembly finally adopted both Covenants unanimously on 16 December 1966; the first Optional Protocol (OP) to the ICCPR, which provides for an individual complaints system, was adopted by 66 votes to 2 (Niger and Togo), with 38 abstentions, including all socialist states.

Most of the highly ideological debates between Western, socialist and Southern states related to the monitoring system. The different positions can be characterized as follows. The Western states considered only civil and political rights as 'real' rights, because they were perceived as solely imposing negative obligations on states, that is, obligations of not interfering with the individual exercise of these human rights and freedoms. As a consequence, they could be monitored by an independent court, such as the European Court of Human Rights, by means of a judicial complaints procedure. Economic, social and cultural rights, which were considered as solely imposing positive obligations on states, were only treated as so-called programme rights to be achieved progressively according to the economic capacities of the respective states. As such, they were perceived as 'non-justiciable'. The Soviet Union and its allies claimed ownership of economic, social and cultural rights and insisted, therefore, on the

states abstained because the right of peoples to self-determination and the minority rights were not included, but they did not claim that there was not enough emphasis on economic, social and cultural rights.

29 UNGA Res 421 (4 December 1950).

30 Humphrey (n 19), 162.

31 UNGA Res 543 (5 February 1952).

32 On the history of the two Covenants see, e.g., the extensive commentary of the UN Secretary General in UN Doc A/2929; Marc Bossuyt, Guide to the 'Travaux Préparatoires' of the International Covenant on Civil and Political Rights (1987); Nowak (n 6), xxiiff; Matthew Craven, The International Covenant on Economic, Social and Cultural Rights - A Perspective on its Development (1995) 6ff; Ben Saul, David Kinley and Jacqueline Mowbray, The International Covenant on Economic, Social and Cultural Rights, Commentary, Cases, and Materials (2014). 
equality and interdependence of all human rights. According to the socialist doctrine of human rights, the state was responsible for the implementation of all human rights through positive action for the benefit of all members of society. Since in the ideal socialist society there was thus no conflict between the interests of individuals and society, individuals had no right to claim their human rights against the state by means of individual complaints before domestic courts, much less before an international court. Every international mechanism for the monitoring of states' compliance with their human rights obligations, including the state reporting system, was seen as an inadmissible interference with state sovereignty and the domestic jurisdiction clause in Article 2(7) UN Charter. During the Cold War, most countries of the Global South were either in the socialist or the Western camp. African states were primarily interested in the fight against colonialism, apartheid and other forms of racism and racial discrimination, and strongly supported the collective rights of peoples to self-determination and development.

\section{THE LEGAL CONSTRUCTION OF THE PROTECTION OF ECONOMIC, SOCIAL AND CULTURAL RIGHTS}

It is almost a miracle that, despite these fundamental ideological differences and in the middle of the Cold War, the diplomats in the United Nations could finally agree on the adoption of the two Covenants with some sort of international monitoring system. However, this compromise had two far-reaching consequences. The international community, based upon largely doubtful theoretical assumptions, decided that the two categories of human rights are legally different and would therefore entail different legal obligations of states. Second, these different legal obligations of states would also require different methods of international monitoring.

With respect to state obligations, Article 2(1) ICCPR requires states parties 'to respect and to ensure to all individuals' the civil and political rights contained therein. Article 2(1) ICESCR, on the other hand, requires each state party only 'to take steps, individually and through international assistance and cooperation, especially economic and technical, to the maximum of its available resources, with a view to achieving progressively the full realization' of the economic, social and cultural rights contained therein. The difference between these two types of state obligations could not have been more drastic. Civil and political rights have to be immediately respected and ensured, and every failure of a state party to respect and ensure them can be qualified as a violation of the respective obligation, and any person claiming to be a victim of such violation has a right to an effective, if possible judicial, domestic remedy in accordance with Article 2(3) ICCPR. Economic, social and cultural rights, on the contrary, are considered as mere 'programme rights'. For states, it seems to be enough to take a few steps, such as asking for international development assistance, in order to prove that they have complied with their respective obligations. They can always claim that they are too poor to provide their people with adequate food, education or health care in the absence of adequate international assistance. In any case, there are no obligations of result, only obligations of conduct to progressively achieve some results in the future.

With respect to international monitoring, the international community did not even find it necessary to appoint an independent expert body to supervise states' compliance with their weak obligations deriving from the ICESCR. States were only requested in Article 16 ICESCR to submit 'reports on the measures which they have adopted and the progress made in achieving the observance of the rights' to the ECOSOC for consideration. In other words, one of the 
major political bodies of the UN, consisting of states represented usually by diplomats with no specific knowledge on the domestic implementation of economic, social and cultural rights, was entrusted to examine these state reports and to submit 'from time to time to the General Assembly reports with recommendations of a general nature' about the progress in achieving economic, social and cultural rights in all states parties in accordance with Article 21 ICESCR.

Article 28 ICCPR, on the contrary, established an independent monitoring body, the Human Rights Committee (HRCttee), consisting of 18 highly qualified independent experts. In addition to examining state reports in accordance with Article 40, the Committee was also entrusted to decide about inter-state and individual complaints as provided for in Articles 41 and 42 ICCPR, as well as in the first OP. Although the two complaints procedures are both optional and are framed in very weak terms ('communications', 'final views' and so on), the HRCttee did its best to develop at least the individual communication procedure into a fairly effective quasi-judicial procedure, similar to the respective judicial procedures before regional human rights courts.

ECOSOC soon realized that it did not have the required time and expertise to examine state reports, and in 1985 established the independent Committee on Economic, Social and Cultural Rights (CESCR), ${ }^{33}$ which developed the state reporting procedure into a fairly effective tool and which adopted far-reaching 'General Comments' on the model of similar comments by the HRCttee, which further developed the legal interpretation of the provisions of the Covenant, including the respective obligations of states. In 2008, the General Assembly, after highly controversial discussions and despite strong opposition by Western states, finally adopted an OP to the ICESCR, which entrusts the Committee to also consider individual and inter-state communications as well as to initiate an inquiry procedure in case of grave or systematic violations of economic, social and cultural rights by a state party.

\section{EQUALITY, INDIVISIBILITY AND INTERDEPENDENCE OF ALL HUMAN RIGHTS}

The interdependence of all human rights was already stressed by the General Assembly when it requested that the Commission draft one single treaty. ${ }^{34}$ Although the Assembly revised this decision one year later, it tried to keep both Covenants as one unity, calling them, together with the UDHR, the 'International Bill of Human Rights', adopting them on the same day and including also some rights with similar language in both Covenants, such as the right of peoples to self-determination in Article 1 and the equal rights of men and women in Article 3. Nevertheless, the differences of state obligations and international monitoring procedures prove that the two categories of human rights were certainly not treated equally. However, the establishment of the CESCR in 1985 and the adoption of the OP to the ICESCR in 2008 were important steps towards treating both categories of human rights more equally than before.

The most important document in this respect is the Vienna Declaration and Programme of Action (VDPA), adopted unanimously by 171 states at the conclusion of the Vienna World Conference on Human Rights in June 1993. ${ }^{35}$ The World Conference was convened in order to

33 ECOSOC Res 1985/17 (28 May 1985).

34 UNGA Res 421 (4 December 1950).

35 UNGA, 'Vienna Declaration and Programme of Action' (12 July 1993) UN Doc A/CONF.157/23. 
use the historic window of opportunity, which had opened by the implosion of the communist regimes in Central and Eastern Europe and the end of the Cold War, to contribute to a new world order based on pluralist democracy, the rule of law and human rights. While the World Conference was being prepared, the situation in many parts in the world rapidly deteriorated and the countries of the Global South accused the West of misusing human rights in support of their neo-colonial aims and dominating globalization with neoliberal economic policies. These accusations led to the claim that human rights were not universal values but a Western concept designed to foster Western (primarily US) hegemony. After long and difficult negotiations, in which NGOs played a decisive role, the drafters were able to find an important compromise, which also paved the way for an agreement on establishing the Office of UN High Commissioner for Human Rights. ${ }^{36}$

Article 5 VDPA reads as follows:

All human rights are universal, indivisible and interdependent and interrelated. The international community must treat human rights globally in a fair and equal manner, on the same footing, and with the same emphasis. While the significance of national and regional particularities and various historical, cultural and religious backgrounds must be borne in mind, it is the duty of states, regardless of their political, economic and cultural systems, to promote and protect all human rights and fundamental freedoms.

Although this formulation looks fairly innocent and self-evident, it constitutes an important compromise. Despite stressing the significance of national and regional particularities, the Global South had finally agreed to the universality of human rights and thus conceded that human rights were not simply a Western concept. This means, in principle, that African or Asian values should no longer be invoked as an argument to put the universal nature of human rights into question. At the same time, Western states agreed to treat all human rights - that is, economic, social and cultural rights as well as civil and political rights - in a fair and equal manner, taking into account their indivisibility, interdependence and interrelatedness. This means, in particular, that the legal differentiation between the two major categories of human rights needs to be revisited and the incorrect assumptions which had dominated the ideological discussions during the Cold War rectified.

The VDPA contains many commitments in this respect, most of which have been implemented in the meantime. They include the adoption of various OPs with the purpose of entrusting all UN treaty monitoring bodies with the power to examine individual communications on an equal basis with the HRCttee. In the meantime, legal human rights scholars have developed a new theory of state obligations deriving equally from all human rights treaties. ${ }^{37}$ This theory proves the Cold War assumption wrong, according to which civil and political rights simply entail negative state obligations, whereas economic, social and cultural rights would only entail positive state obligations. Reality looks, however, totally different. There is no civil or politi-

36 On the role of NGOs see, e.g., Manfred Nowak (ed.), World Conference on Human Rights, Vienna, June 1993: The Contribution of NGOs, Reports and Documents (1994).

$37 \quad C f$., e.g., Eide (n 4), 9; Martin Scheinin, 'Economic and Social Rights as Legal Rights' in Asbjørn Eide, Catarina Krause and Allan Rosas (eds), Economic, Social and Cultural Rights (2001) 29; Manfred Nowak, Introduction to the International Human Rights Regime (2003) 23ff, 48ff. See also the Limburg Principles on the Implementation of the International Covenant on Economic, Social and Cultural Rights, in (1987) 9 HRQ 122; and the Maastricht Guidelines on Violations of Economic, Social and Cultural Rights, in (1998) 20 HRQ 1. 
cal right which can be effectively enforced by states by simply doing nothing. The right to life does not only mean that the police should not kill people arbitrarily. At a minimum, the state must enact laws that regulate the powers and responsibilities of the police and the procedure to be followed in case the police kill somebody. In addition, the police need proper training in order to ensure that as few people as possible are killed arbitrarily. However, in most states the risk of being killed by the police is much smaller than the risk of being killed by criminals, by car accidents or by avoidable diseases. This means that the state has a responsibility to ensure that the crime rate in relation to murder and homicide is not getting out of hand, that car traffic is properly regulated and that the public health system is functioning properly. In other words, the state has many different obligations: to respect the right to life (negative obligation not to interfere with the right to life through arbitrary killings by the police or military); to protect the right to life against criminals, terrorists or other private actors; and to fulfil the right to life by a broad variety of positive measures, such as enacting police laws, training police officials, regulating car traffic and maintaining a well-functioning public health system.

The same is true for economic, social and cultural rights. Of course, the right to education requires states to build schools, to recruit and train teachers and to take many other positive measures aimed at providing a well-functioning primary, secondary and higher education system, as well as vocational and other training. In addition to these obligations to fulfil, the right to education also requires states to protect children against abusive school teachers and to respect the liberty of parents to establish their own private schools or to organize the education of their children in accordance with their own moral and religious convictions, without undue interference by governmental authorities. There are many other convincing examples to show that every civil, political, economic, social and cultural right entails both negative obligations to refrain from interference and positive obligations to protect individuals against powerful private parties and to fulfil the respective rights by means of positive legislative, administrative, judicial and political measures.

These few examples show that it is wrong to talk about 'positive and negative rights' or about rights which entail negative duties to refrain from interference, whereas other rights would entail only positive duties to fulfil and to protect. Positive and negative obligations are inherent in every human right. There might be rights where the positive obligations are more important than the negative obligations and vice versa, but in principle, every human right entails negative state obligations to refrain and positive state obligations to protect and to fulfil. Negative obligations are immediately and directly applicable, whereas positive obligations are subject to the principle of due diligence. This means that states are under an obligation to do whatever can reasonably be expected from them in light of their political, economic and other possibilities. Positive obligations can never be completely fulfilled. There will always be people who die from crime, car accidents and preventable diseases. However, the state can only be held accountable for violating its positive obligations to protect and fulfil the right to life if it has not taken any reasonable action to prevent these causes of death. It is the 'art of human rights' to decide in a specific individual case where to draw the line. The same holds true for the right to education. If children are excluded from public primary schools because they are female, black or gay, the state violates its negative to respect the right to education. If there are, however, not enough public primary schools to provide 100 per cent school enrolment due to a lack of funds, it is a question of due diligence to decide whether the state has taken all measures that can reasonably be expected from that state or not. 


\section{Research handbook on international law and social rights}

By definition, positive obligations can never be fully complied with. This means that positive obligations to protect and to fulfil are always subject to the principle of progressive implementation, irrespective of the fact whether these positive obligations derive from a civil or political right or from an economic, social or cultural right. It follows that the distinction between legal obligations according to the type of human rights, as stipulated in Article 2 of both International Covenants, is simply wrong as it is based on false assumptions that were used as ideological arguments during the Cold War. It also follows that all human rights are justiciable. Of course, the assessment of the implementation of negative obligations is usually easier for courts than the assessment of whether or not a state has taken all measures that can reasonably be expected from that state in order to protect and fulfil certain human rights. But this is not a matter for economic, social and cultural rights alone.

\section{SOCIAL RIGHTS}

As outlined above, the rights to social security and an adequate standard of living are at the core of social rights in Article 25 UDHR, a provision which has been elaborated in a more detailed manner in Articles 9 to 12 ICESCR. The travaux préparatoires of the UDHR and the ICESCR show that the term 'social security' has been used in a broad sense in Article 22 UDHR and in a more narrow sense in Article 25 UDHR and 9 ICESCR. ${ }^{38}$ In the original drafts, Article 22 UDHR was meant to secure a right to social security in the narrow sense of protecting individuals against hardship in the event of unemployment, sickness, disability or old age. ${ }^{39}$ However, René Cassin and others then developed the idea of combining this right with an umbrella article at the beginning of the section on economic, social and cultural rights. ${ }^{40}$ The combination of such an umbrella article with the right to social security created lengthy debates about the meaning of the term 'social security' in the Commission and later in the Third Committee of the General Assembly. Some delegates would have preferred the term 'social justice' in the umbrella article, but both René Cassin and Eleanor Roosevelt did not wish to give up the term 'social security', which had been coined by Franklin D Roosevelt's Social Security Act of 1935. It follows that 'social security' in Article 22 UDHR is also used as an umbrella term in the sense of social justice or freedom from want. As the umbrella term 'personal security', as laid down in Article 3 UDHR, can be understood to guarantee human beings a life in freedom from fear and violence, ${ }^{41}$ 'social security' in the broader sense of Article 22 UDHR aims at ensuring a life in freedom from want and poverty. This shall be realized through the implementation of all economic, social and cultural rights, through national effort and international cooperation, as emphasized in Article 22 UDHR.

The concept of social rights is defined in Article 25 UDHR by another umbrella right: the right to an adequate standard of living. It includes a number of more specific social rights, such as the rights to food, clothing, housing, health (medical care) and social security in the more narrow sense, that is, to provide to everyone the necessary social services 'in the event

\footnotetext{
38 See Andreassen (n 23), 461ff; Eide and Eide (n 20), 524ff; Manfred Nowak, Human Rights or Global Capitalism (n 9), $81 \mathrm{ff}$.

39 See, e.g., the draft of Article 22 presented to the Commission in 1948, UN Doc E/CN.4/127.

40 See Andreassen (n 23), 470.

41 On the right to personal security, see Nowak, Human Rights or Global Capitalism (n 9), $138 \mathrm{ff}$.
} 
of unemployment, sickness, disability, widowhood, old age or other lack of livelihood, in circumstances beyond his control'. In Article 25(2), special care and assistance to motherhood and childhood were added to the umbrella social right of an adequate standard of living. During the drafting of the ICESCR, it was felt necessary to split the various elements of the umbrella social right to an adequate standard of living into various separate social rights and to define them in more specific terms. The right to medical care was transformed into a separate right to the enjoyment of the highest attainable standard of physical and mental health in Article 12 ICESCR. The right to social security, 'including social insurance', was kept remarkably short as a separate right in Article 9 ICESCR under the understanding that it reflected the nine pillars of the ILO Convention No 102 concerning Minimum Standards of Social Security of 1952. Assistance to motherhood and childhood was further developed into a general right of protection and assistance to the family as the 'natural and fundamental group unit of society' in Article 10 ICESCR, and the remaining part of the right to an adequate standard of living, including the rights to food, clothing and housing, was retained in Article 11 ICESCR.

States have a primary obligation to fulfil these social rights by adopting comprehensive legislation in the fields of social security, including social insurance, in the event of sickness, disability, injury, unemployment, maternity, old age or death of a family member; protection of the family, motherhood and childhood; food security and food assistance in emergency situations; and access to social housing, clean and affordable water, sanitation and affordable medical care. States must build hospitals and primary health care centres; educate, train, recruit and pay doctors, nurses and other health care personnel; provide social housing for the poor; establish social insurance and pension funds; and take care of the elderly, orphans, street children, persons with disabilities, homeless and jobless people, the poor, refugees, internally displaced persons and other vulnerable groups. Not all of these social services must be provided directly by the state and they may be outsourced to private hospitals, private doctors, private orphanages or old people's homes. However, there are clear limits to privatization of these core governmental functions,${ }^{42}$ and states have an obligation to protect individuals, above all the poor, disadvantaged, discriminated and vulnerable sectors of society, against being excluded from these social services or being evicted from their lands, homes and so on. Furthermore, states have an obligation to respect these social rights by ensuring that everybody has equal access to these essential social services and that nobody is excluded and left behind. Finally, it is of utmost importance that all these rights are laid down in domestic law as justiciable rights, and that everybody has the right to an effective remedy to claim these rights before domestic courts with free legal aid, legal counselling and legal assistance.

\section{CONCLUSIONS AND OUTLOOK}

One of the great achievements of the 1948 UDHR is that it defined the term 'human rights' in the Charter of the United Nations in a broad sense, incorporating both the 'Western concept' of civil and political rights and the 'socialist concept' of economic, social and cultural rights. This reflects the antifascist consensus, immediately after the end of the Second World War, that the new world order to be established in reaction to two world wars, the Great Depression, the rise

42 See Nowak, Human Rights or Global Capitalism (n 9), 77ff, $91 \mathrm{ff}, 109 \mathrm{ff}$. 
of fascism and the horrors of the Holocaust required strong liberal and, at the same time, social welfare states in which the enjoyment of freedom from want and poverty was as important as the enjoyment of freedom from fear and violence. However, during the time of the Cold War the Western states, both in their domestic constitutions and in regional organizations such as the $\mathrm{CoE}$ and the OAS, clearly gave preference to civil and political rights, whereas economic, social and cultural rights were considered as mere 'programme rights'. In 1950 the member states of the CoE adopted the ECHR, which contained only civil and political rights and established a strong regional monitoring system with the European Court of Human Rights as the first regional human rights court, whereas the ESC was only adopted in 1961, with far weaker legal obligations of states and a much weaker regional monitoring mechanism. From a terminological point of view, the CoE uses the term 'social rights' for the entire category of human rights, which in the United Nations and other organizations is usually called 'economic, social and cultural rights'. In the constitutions of the newly emerging socialist states of that time, above all in Central and Eastern Europe, a clear preference was given to economic, social and cultural rights.

In the United Nations, in 1952 the Western states succeeded in the General Assembly in reversing an earlier decision and abandoning the original idea of drafting, on the basis of the UDHR, a universal convention which would include all human rights on an equal basis. Instead, two different Covenants were drafted and finally adopted in 1966 as part of the 'International Bill of Human Rights': a 'Western' ICCPR and a 'socialist' ICESCR. With this splitting of the 'International Bill of Human Rights' into two pieces, the international community also agreed, on the basis of largely doubtful theoretical assumptions, that the two categories of human rights are legally different and would entail, therefore, different legal obligations of states which would require different methods of international monitoring. In short, this largely ideological construction assumed that civil and political rights were purely 'negative rights' which only entailed the negative obligation of states to refrain from violating these rights. Since these negative obligations were immediately binding, they could also be subjected to international monitoring by international or regional human rights courts on the basis of inter-state and individual complaints. Economic, social and cultural rights, on the other hand, were constructed as purely 'positive rights' which only entailed positive obligations of states to take steps with a view to achieving progressively their full realization. These positive obligations were not understood as immediately legally binding and, therefore, as 'non-justiciable'. States were only required to submit reports about the measures they had taken to implement these rights, which were reviewed by the ECOSOC of the United Nations, similarly to the reporting procedure under the ESC before the Committee of Ministers of the CoE.

After the implosion of the Communist states in Central and Eastern Europe and the end of the Cold War, this ideological construction of two different legal categories of human rights was challenged in both theory and practice. The outcome document of the Vienna World Conference on Human Rights in 1993 - the VDPA, which is the basis for the establishment of the Office of the United Nations High Commissioner for Human Rights and the post-Cold War human rights programme of the world organization - explicitly confirmed the universality, indivisibility, interdependence and equality of all human rights. Politically speaking, this meant that the states of the Global South accepted that human rights were a universal and not only a Western concept, as Asian and African states often used to claim. On the other hand, Western states accepted that the legal distinction between civil and political rights on the one hand, and economic, social and cultural rights on the other, was nothing but an ideological 
construction during the time of the Cold War. On the basis of the Vienna consensus, human rights scholars and monitoring bodies developed the theory that all human rights entail negative obligations of states to respect them and positive obligations to fulfil them by appropriate legislative, administrative, judicial, political and other means, as well as to protect them against interference by private parties. The negative obligation to respect any human right is violated when states take measures that interfere with such right in a manner that cannot be justified. The positive obligation to fulfil or protect a right is violated if states fail to take the necessary steps that can reasonably be expected from them (under the principle of due diligence) with a view to progressively achieving the full realization of that right. Both types of obligations are 'justiciable', although it might be a little more difficult for courts to assess at which point states violate their positive obligation to take sufficiently strong measures of implementation. On the other hand, the European, Inter-American and African human rights courts also need to balance, in most cases of negative state obligations, whether the respective interference by the state was justified by legitimate state interests or not.

In practice, much has been achieved to overcome the ideological distinction between the two categories of human rights. Domestic courts, most notably the Constitutional Court of South Africa and the Supreme Court of India, have proven, in a number of landmark judgments, that economic, social and cultural rights are fully 'justiciable'. On the basis of the VDPA, the United Nations adopted various Optional Protocols to existing human rights treaties which recognized the right of victims to lodge individual complaints also in relation to economic, social and cultural rights, above all the Optional Protocol to the ICESCR of $2008 .{ }^{43}$ On the basis of these Optional Protocols, the respective UN treaty monitoring bodies have rendered an increasing number of decisions relating to economic, social and cultural rights. In 1995, the CoE had already adopted an Additional Protocol to the ESC which established at least a collective complaints system before the European Committee of Social Rights. ${ }^{44}$ However, neither the CoE, nor the United Nations, or any other international or regional organization has done enough to fully implement the indivisibility, interdependence and equality of all human rights. Economic, social and cultural rights are still considered in many countries of the world as far less important than civil and political rights. Moreover, the current neoliberal global economic system, with its emphasis on privatization, deregulation and minimizing the role of the state, has contributed to a massive reduction of the social welfare economy in many countries, both in the Global North and the Global South, and the current international and regional mechanisms for the protection of economic, social and cultural rights are far too weak to effectively prevent or stop such a powerful global trend. ${ }^{45}$

Social rights are at the centre of economic, social and cultural rights and suffer most under the current neoliberal economic system. The core social rights to social security and an adequate standard of living, including the rights to food, water, housing and health, as provided for in Article 25 UDHR, are most under attack if states are no longer able or willing to uphold a social welfare system and to protect the freedom from want and poverty proclaimed almost

43 UNGA Res 63/117 (10 December 2008).

44 For the Additional Protocol to the European Social Charter and the respective case law of the European Committee of Social Rights see the contribution by Karin Lukas in this Research Handbook (Chapter 7).

\footnotetext{
${ }_{45}$ See Nowak, Human Rights or Global Capitalism (n 9); Nowak, Menschenrechte - Eine Antwort (n 9).
} 
80 years ago by US President Roosevelt. If we wish to fulfil the vision of Article 28 UDHR, namely the right of all human beings to a 'social and international order in which the rights and freedoms set forth in this Declaration can be fully realized', we need to drastically reduce economic inequality and to fundamentally reform the current global economic system. The full implementation of the 'Agenda 2030' with its 17 Sustainable Development Goals (SDGs), ${ }^{46}$ which in fact contains most economic, social and cultural rights and demands a reduction of economic inequality (SDG 10), would be a major step in the right direction.

46 UNGA Res A/70/1 (25 September 2015) 'Transforming Our World: The 2030 Agenda for Sustainable Development'. 